\title{
Sedimentary facies, processes and environments of the Akakura caldera lake, the South Kurikoma geothermal area, northeast Japan
}

\author{
Masami Otake* \\ Received 23 August, 2006 \\ Accepted 14 September, 2007 \\ * Institute of Astrophysics and Earth Sciences, \\ Graduate School of Science and Engineering, \\ Ibaraki University, Bunkyo 2-1-1, Mito 310- \\ 8512, Japan \\ * Mitsubishi Gas Chemical Company, Inc. Energy \\ and Resources Division, Marunouchi 2-5-2, \\ Chiyoda-ku, Tokyo 100-8324, Japan \\ M. Otake, masami-otake@mgc.co.jp
}

\begin{abstract}
The Pleistocene Kan-nodai Formation was deposited in the collapse basin formed by felsic volcanism of the Akakura caldera, South Kurikoma geothermal area, northeast Japan. The middle and upper members of the Kan-nodai Formation represent postcaldera lacustrine slope apron and basin plain deposits of the Akakura caldera. The slope apron deposits consist mainly of interbedded sandstone and mudstone and massive tuff breccia deposited from turbidity currents and debris flows that resulted from slope failures of the unstable caldera wall. The beds are laterally continuous and show neither systematic vertical depositional patterns nor distinctive erosional features. Slump beds are common, indicating slope instability. The basin plain deposits overlie the slope apron deposits and are dominated by fine-grained turbidites and debris flow deposits, and suspension fallout deposits, indicating that coarse-sediment supply is not affected. Plant fossils are abundant. The slope apron and basin plain deposits include voluminous graded pumice lapilli tuff. A fining-upward succession from the slope apron to the basin plain deposits reflects retreat of the caldera wall due to slope failures, and rise of lake level with increasing water volume within the caldera basin. The lake deposits record volcanic activities of the felsic pyroclastic eruption in the area east of the lake and the postcaldera andesitic effusive eruption in the southeastern part of the caldera.
\end{abstract}

Key words: facies analysis, slope apron, basin plain, caldera lake, Akakura caldera, Pleistocene, Kurikoma, Yamagata prefecture, Miyagi prefecture
Introduction

The South Kurikoma geothermal area, northeast Japan, includes some calderas overlapping each other (Fig. 1), formed as a result of subaerial felsic volcanism along the Backbone Range in northeast Japan during the Late Miocene and Quaternary (e.g. Awata, 1984; Amano and Sato, 1989; Ito et al., 1989). The Pleistocene Kan-nodai Formation represents the caldera fill accumulated in the Akakura caldera and records sedimentary and volcanic processes after collapse of the caldera. The primary volcanic processes that formed the Akakura caldera have been reported by Otake (2000). This paper focuses on the lacustrine deposits that occupy middle and upper members of the Kan-nodai Formation and discusses the postcaldera events in the caldera lake. Basin-filling processes after caldera collapse are poorly understood, although lacustrine deposits have been described in detail by Yamada (1972) and Utada and Ito (1989).

\section{Geologic setting}

The Akakura caldera has a north-south diameter of 10

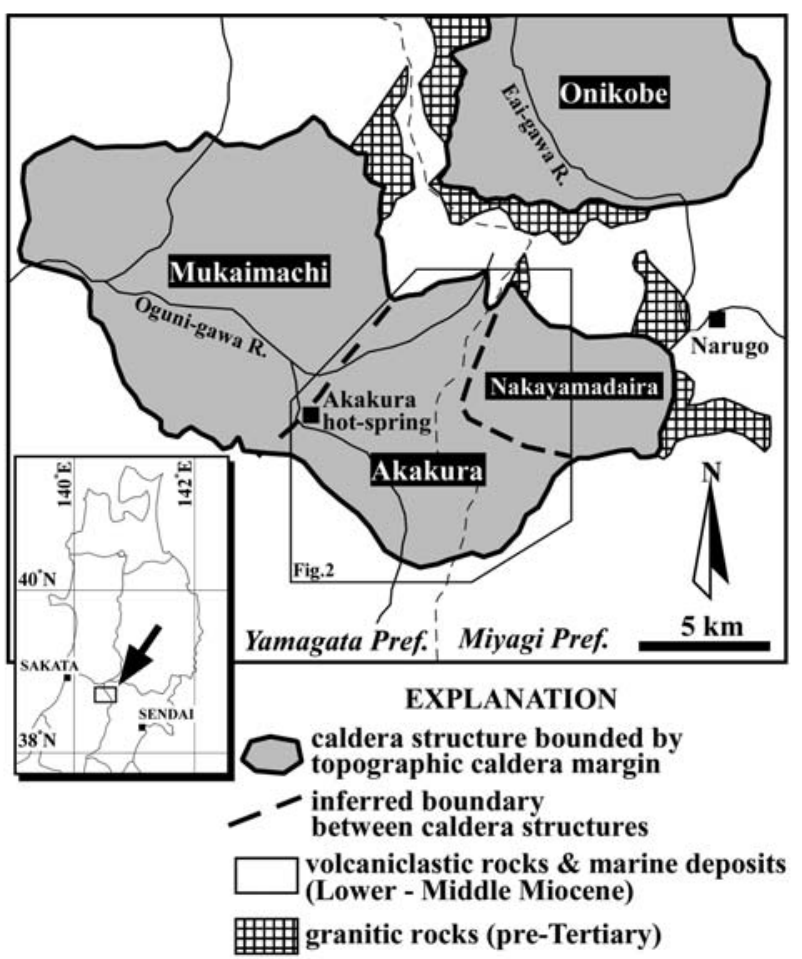

Fig. 1. Location map showing the distribution of the caldera struc549 tures in the South Kurikoma geothermal area. 

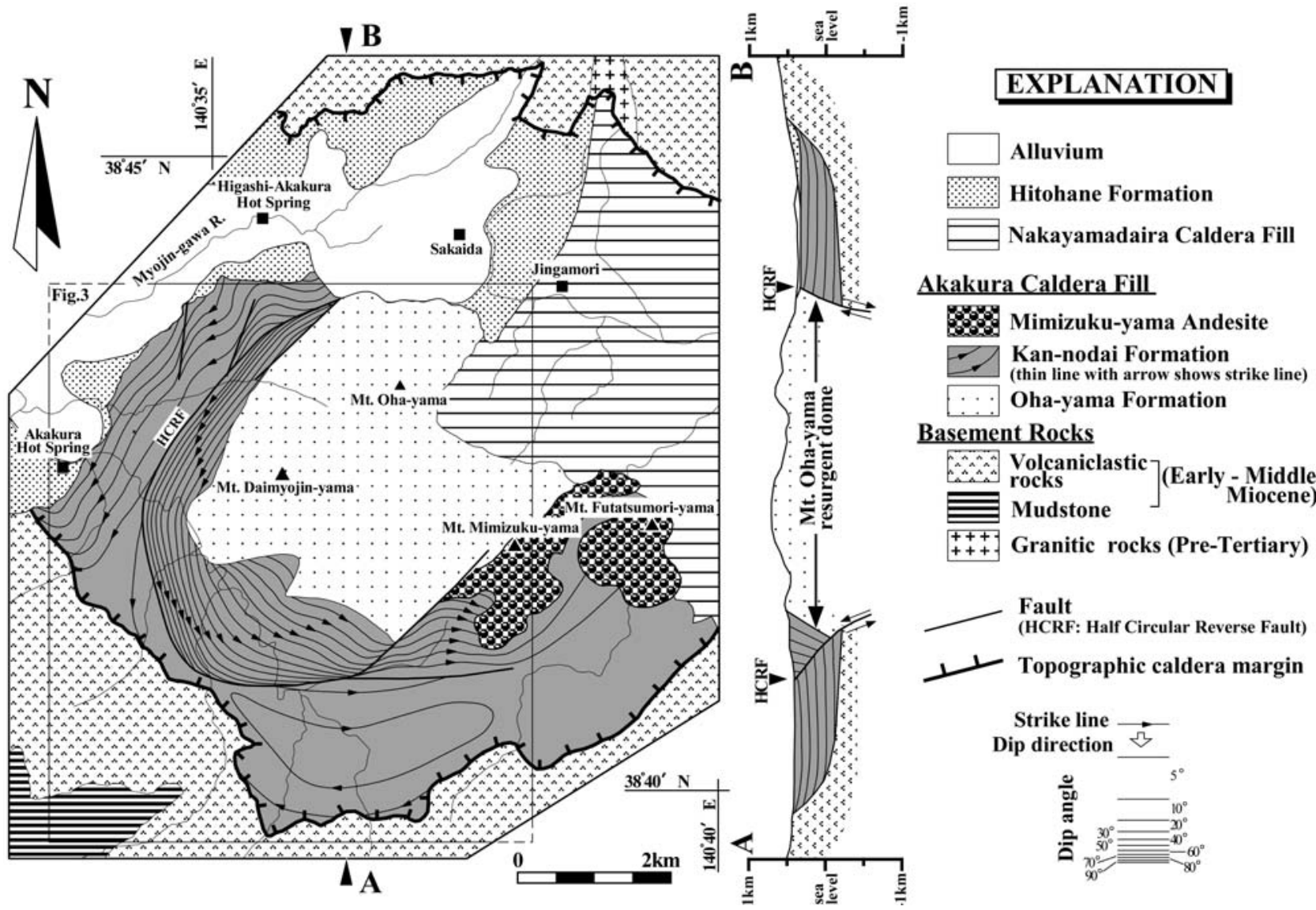

Fig. 2. Geologic map and cross section of the Akakura caldera. Modified from Otake (2000).

$\mathrm{km}$ and east-west diameter of $9 \mathrm{~km}$, and is located on the border of Yamagata and Miyagi Prefectures in the southern part of the Kurikoma geothermal area (Fig. 1). According to Otake (2000), the caldera is a Valles-type caldera (Smith and Bailey, 1968), which is equivalent to a plate-subsidence type (Lipman, 1997), because of the presence of pre-caldera regional tumescence, the pattern of gravity anomalies, lithofacies of the caldera fill, vents along the structural boundary, and a resurgent dome. The basement rocks, which bound the northern and southern margins of the caldera, are pre-Tertiary granitic rocks, Miocene subaqueous volcaniclastic rocks and mudstones. The caldera fill is over $1,400 \mathrm{~m}$ thick and consists of the Oha-yama Formation (Morimoto, 1942), the Kan-nodai Formation (Taguchi, 1961) and the Mimizuku-yama Andesite (Fig. 2). Description of the caldera fill has been presented by Otake (2000) and is summarized as follows.

The Oha-yama Formation, which forms a resurgent dome (Mt. Oha-yama resurgent dome) proposed by Otake (2000), is distributed in the central part of the caldera, and is either uncomformably overlain by or in fault contact with the Kan-nodai Formation. This formation consists of felsic welded lapilli tuff and poorly sorted tuff breccia, which are regarded as caldera-forming ash-flow tuffs and debris-avalanche deposits from the caldera walls respectively. Otake (2000) considered that the calderaforming eruption occurred in the Pliocene or Pleistocene based on radiometric ages and stratigraphic relationships of the caldera fill. Kondo et al. (2004) reported a fission track age of $1.0 \pm 0.3 \mathrm{Ma}$.

The Kan-nodai Formation is divided into lower, middle and upper members (Figs. 3 and 4). The lower member ranges in thickness from 200 to $250 \mathrm{~m}$ and consists of breccia and sandstone with sheet-like bed geometries. The middle member is 250 to $300 \mathrm{~m}$ thick and consists of mudstone, sandstone, breccia, and tuff. The upper member ranges in thickness from 100 to $150 \mathrm{~m}$ and is characterized by mudstone and tuff with abundant plant fossils (Akakura flora; Uemura, 1977).

The Mimizuku-yama Andesite is distributed in Mt. Mimizuku-yama and Mt. Futatsumori-yama in the southeastern part of the caldera. This andesite consists of coherent lava and hyaloclastite and formerly has been called Mimizuku-yama "Dacite" (Taguchi, 1975; Otake, 2000). The rock is, however, porphyritic and contains phenocrysts of plagioclase, augite, hypersthene and trace 


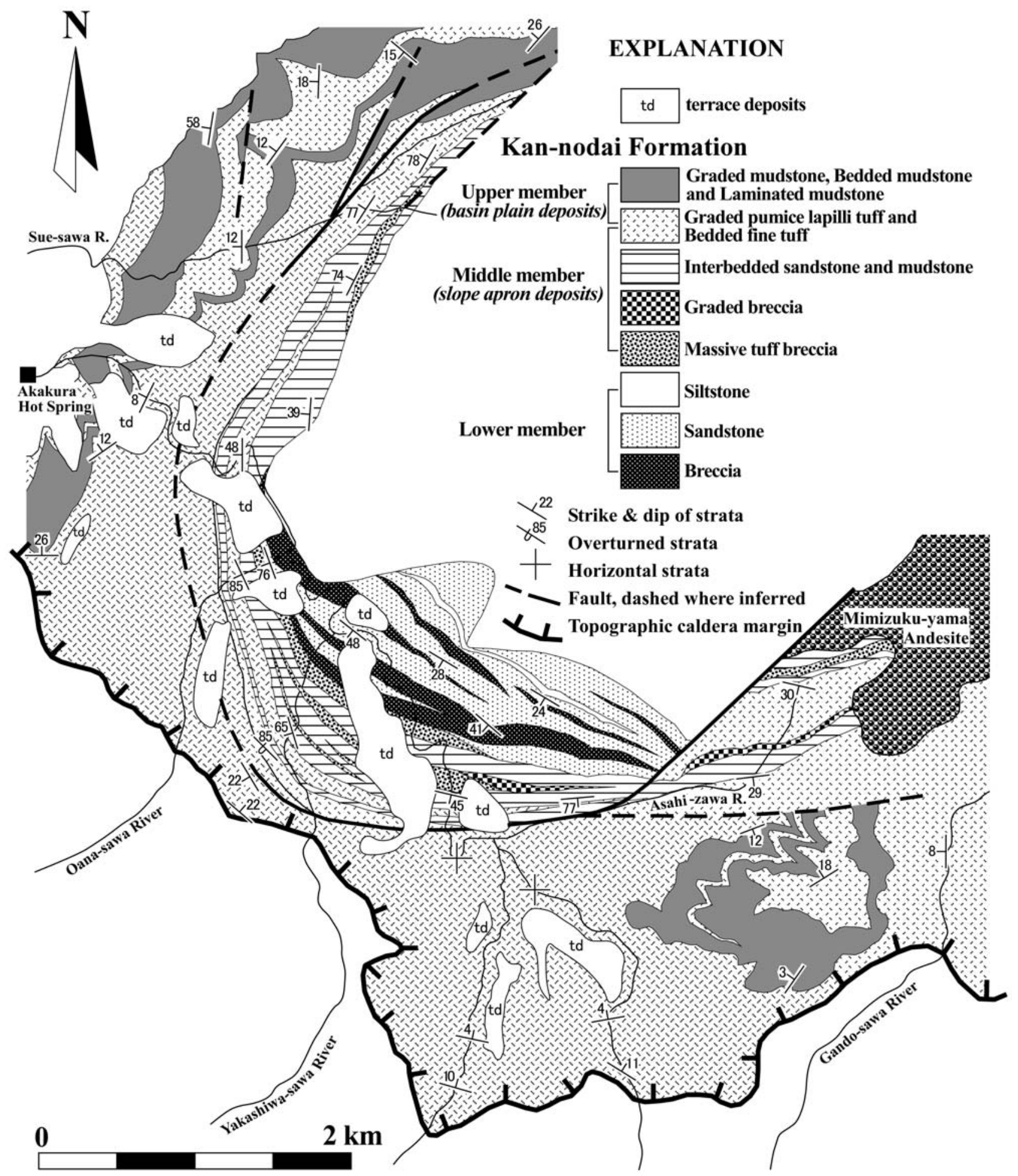

Fig. 3. Map showing the distribution of the facies and the facies associations. Some facies are emphasized in the map because of the narrow distributions.

amounts of opaque minerals with water-free $\mathrm{SiO}_{2}$ content of 59 to 63 wt.\%. Thus, the term Mimizuku-yama "Andesite" is used in this paper.

In the northern and the eastern parts, the Akakura caldera fill is uncomformably overlain by the Hitohane
Formation (Taguchi, 1961) and the Nakayamadaira caldera fill, respectively. The Hitohane Formation is about $80 \mathrm{~m}$ thick and comprises tuff breccia and alternating beds of conglomerate and sandstone with lignite beds. The Nakayamadaira caldera fill is about $250 \mathrm{~m}$ thick and 


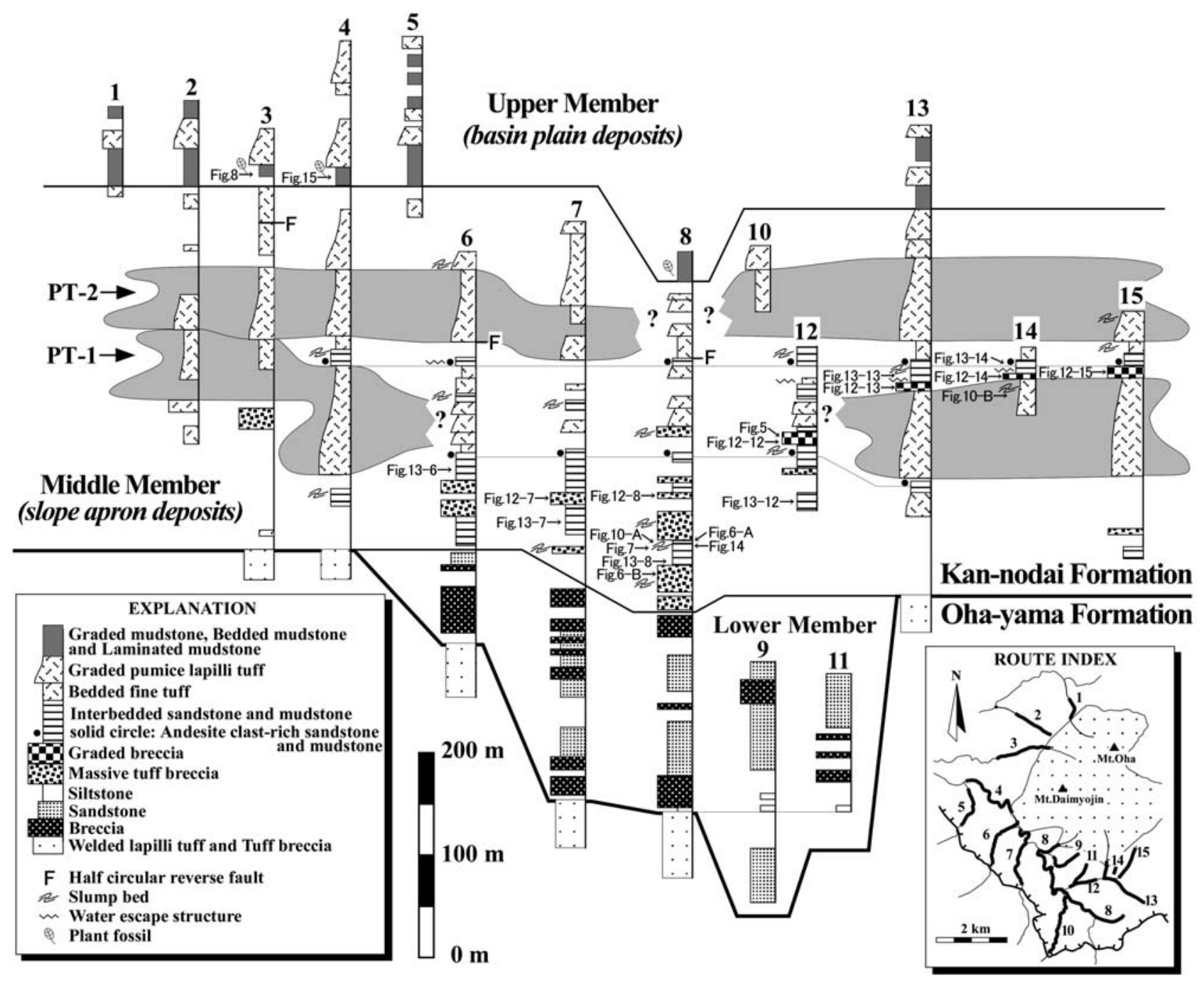

Fig. 4. Geologic columns of the Kan-nodai Formation showing the facies and the facies associations. Facies of mudstones are emphasized in the columns. PT-1 and PT-2 denote thick, widespread graded pumice lapilli tuffs described by Otake (2004).

consists mainly of tuff breccia, pumice lapilli tuff, pumice breccia, and siltstone.

\section{Sedimentary features of the caldera fill}

The middle and upper members of the Kan-nodai Formation consist of eight types of deposits: (1) graded breccia, (2) massive tuff breccia, (3) interbedded sandstone and mudstone, (4) graded mudstone, (5) bedded mudstone, (6) laminated mudstone, (7) graded pumice lapilli tuff, and (8) bedded fine tuff (Table 1). Lateral and vertical distributions of these deposits are shown in Figs. 3 and 4 , respectively.

\section{Graded breccia}

Description: Single deposits of this facies comprise three successive units: (1) lower, inversely-to-normally graded breccia; (2) middle, normally graded, stratified breccia; and (3) upper, stratified gravelly sandstone. The bed thickness of each deposit ranges from $50 \mathrm{~cm}$ to about 15 m. No large-scale erosional discordances are observed.

The lower inversely-to-normally graded breccia is supported by angular to sub-angular cobbles and boulders of basement rocks and andesite (the Mimizuku-yama Andesite), with a matrix of medium to very coarse sands and granules of the same origin (Fig. 5.A). Rip-up clasts are often concentrated in a particular horizon, concentrated in a particular horizon some of which are elongated to a few tens of centimetres parallel or perpendicular to bedding planes. The base is commonly flat and scours the underlying beds in places. The middle normally graded, stratified breccia shows poorly defined planar or lowangle cross-stratification of coarse- and fine-clast-dominated layers (Fig. 5.B). The upper stratified gravelly sandstone consists of fine to medium sands with a small amount of granules. Interstratified layers are fining and 
Table 1. Summarized description and interpretation of the facies observed in the middle and upper members of the Kan-nodai Formation.

\begin{tabular}{|c|c|c|}
\hline Facies & Description & Interpretation \\
\hline Graded breccia & $\begin{array}{l}\text { Clast-supported, polymictic. A fining-upward sequence comprising inversely-to- } \\
\text { normally graded breccia, normally graded stratified breccia, and stratified } \\
\text { gravelly sandstone. Non-channelized base. } 0.5 \text { to } 15 \mathrm{~m} \text { thick. }\end{array}$ & $\begin{array}{l}\text { Deposition from high- and low-density } \\
\text { gravelly tubidity current }\end{array}$ \\
\hline Massive tuff breccia & $\begin{array}{l}\text { Non-stratified, poorly sorted, tuffaceous mud matrix-supported, polymictic. } \\
\text { Non-channelized sharp and flat base. } 5 \text { to } 35 \% \text { of clast content. A few tens of } \\
\text { centimetres to } 10 \mathrm{~m} \text { thick. }\end{array}$ & Deposition from cohesive debris flow \\
\hline $\begin{array}{l}\text { Interbedded sandstone } \\
\text { and mudstone }\end{array}$ & $\begin{array}{l}\text { Sandstone: a fining-upward sequence comprising normally graded, parallel- to } \\
\text { ripple cross-laminated portions. A few centimetres to } 20 \mathrm{~cm} \text { thick. } \\
\text { Mudstone: massive, structureless. Sharp boundary with sandstone. }<1 \mathrm{~cm} \text { thick. }\end{array}$ & Deposition from low-density turbidity current \\
\hline Graded mudstone & $\begin{array}{l}\text { Normally graded with basal very fine- to fine-sand grade parts. Sharp and flat or } \\
\text { weakly scoured base. Several centimetres to } 1 \mathrm{~m} \text { thick. }\end{array}$ & Deposition from fine-grained turbidity current \\
\hline Bedded mudstone & $\begin{array}{l}\text { Massive, structureless with scattered fine-grained organic matter. Sharp and flat } \\
\text { base. } 10 \text { to } 50 \mathrm{~cm} \text { thick. }\end{array}$ & Deposition from cohesive debris flow \\
\hline Laminated mudstone & $\begin{array}{l}\text { Structureless, flat and laterally continuous laminae. Varve-like couplets in some } \\
\text { places. Several millimetres to } 10 \mathrm{~mm} \text { thick. }\end{array}$ & Suspension fallout in a standing body of water \\
\hline Graded pumice lapilli tuff & $\begin{array}{l}\text { A fining-upward sequence divided into five successive layers (see Fig.9). } \\
\text { Abundant lapilli- to block-sized pumice clasts with lithic clasts, crystals and } \\
\text { glass. A few tens of centimetres to about } 50 \mathrm{~m} \text {, up to } 100 \mathrm{~m} \text { thick. }\end{array}$ & $\begin{array}{l}\text { Deposition from high- and low-density } \\
\text { tubidity current }\end{array}$ \\
\hline Bedded fine tuff & $\begin{array}{l}\text { Structureless, well-sorted vitric ash. Flat and sharp base. Laterally continuous. } \\
5 \text { to } 70 \mathrm{~cm} \text { thick. }\end{array}$ & Fallout through a standing body of water \\
\hline
\end{tabular}

thinning upward and rarely grade upward into parallel laminated siltstone (Fig. 5.B).

Interpretation: Deposits of this facies are interpreted as high- to low-density turbidites (Lowe, 1982). The lower inversely-to-normally graded breccia is comparative with R2 and R3 of Lowe's division. The middle normally graded, stratified breccia is equivalent to the $\mathrm{S} 1$ division. The upper stratified gravelly sandstone is similar to the tractional division (Tt) of successive dilute low-density turbidity currents.

\section{Massive tuff breccia}

Description: Deposits of this facies are non-stratified, poorly sorted and matrix-supported (Fig. 6), and are a few tens of centimetres to about $10 \mathrm{~m}$ thick. The clasts are mostly angular to sub-angular cobbles and boulders of basement rocks and andesite (the Mimizuku-yama Andesite) supported by a tuffaceous mud matrix. Clast contents range from 5 to $35 \%$. The bases are generally flat and sharp, or gently scour the underlying beds.

Interpretation: This facies is interpreted to have been deposited from a debris flow. The muddy matrix-supported structure implies that cohesive matrix strength has played an important role for the grain support mechanism (Middleton and Hampton, 1976).

\section{Interbedded sandstone and mudstone}

Description: Interbedded sandstone and mudstone is characterized by alternations of light bluish grey to light brownish grey sandstone (a few centimetres to about 20 $\mathrm{cm}$ thick) and mudstone (a few millimetres to about $1 \mathrm{~cm}$ thick). The beds of this facies are laterally continuous at
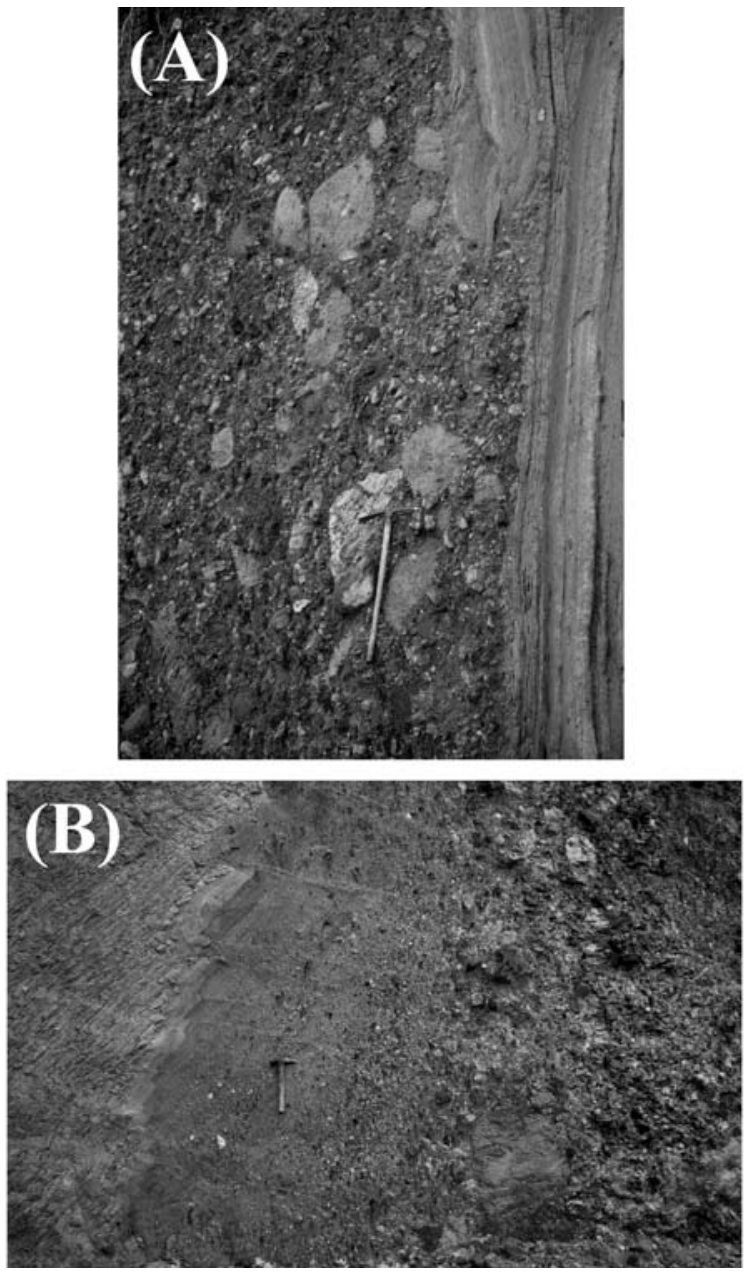

Fig. 5. Photograph of graded breccia. Upsection is to left. Locality is shown in Fig. 4. (A) Inversely-to-normally graded breccia. Hoe is about $90 \mathrm{~cm}$ long. (B) Normally graded breccia grades upward into parallel laminated siltstone through stratified gravelly sandstone layer. 

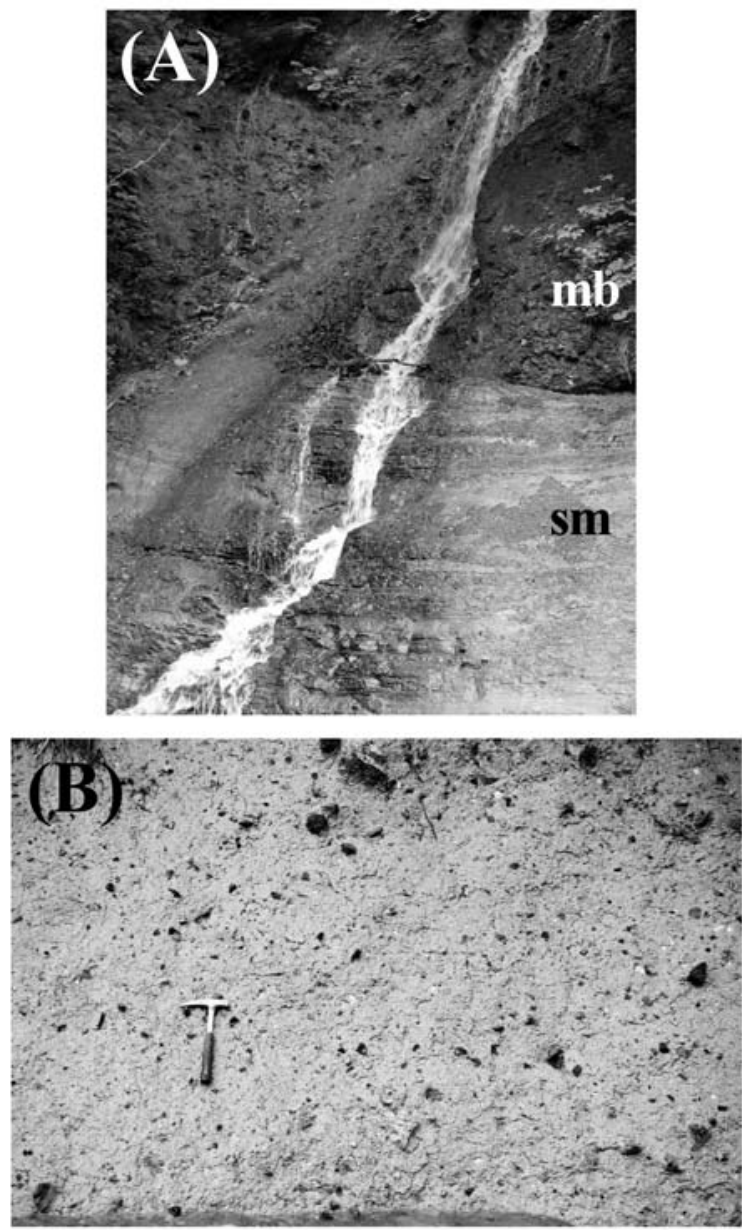

Fig. 6. Photograph of massive tuff breccia. Locality is shown in Fig.4. (A) Massive tuff breccia (mb) overlies an interbedded sandstone and mudstone (sm) with a sharp scoured base. Height of view is about $8 \mathrm{~m}$. (B) Relatively low clast content (5-7 \%) in tuffaceous mud matrix.

least on outcrop scale (Fig. 7.A).

Sandstone layers are normally graded with sharp, planar or locally undulating bases and are parallel- to ripple cross-laminated in the upper parts. The lower graded portions are made up of coarse- to medium-sand-sized angular to sub-rounded lithic and crystal fragments, white to light-grey-coloured rounded to sub-rounded pumice fragments and carbonized organic materials. Rip-up mud clasts are rare. In many cases, the basal graded portions are absent from the sandstone layers. The upper parallellaminated parts are alternations of light-coloured (pumice dominated) laminae and dark-coloured (lithic dominated) laminae less than a few millimetres thick (Fig. 7.B). Pumice fragments are medium- to fine-sand-sized and locally imbricated. The ripple laminations in the overlying parts show a rounded asymmetrical profile (Fig. 7.B). Climbing ripples and convolute laminations are absent. Relatively thick units have cosets of low-angle cross-lam-
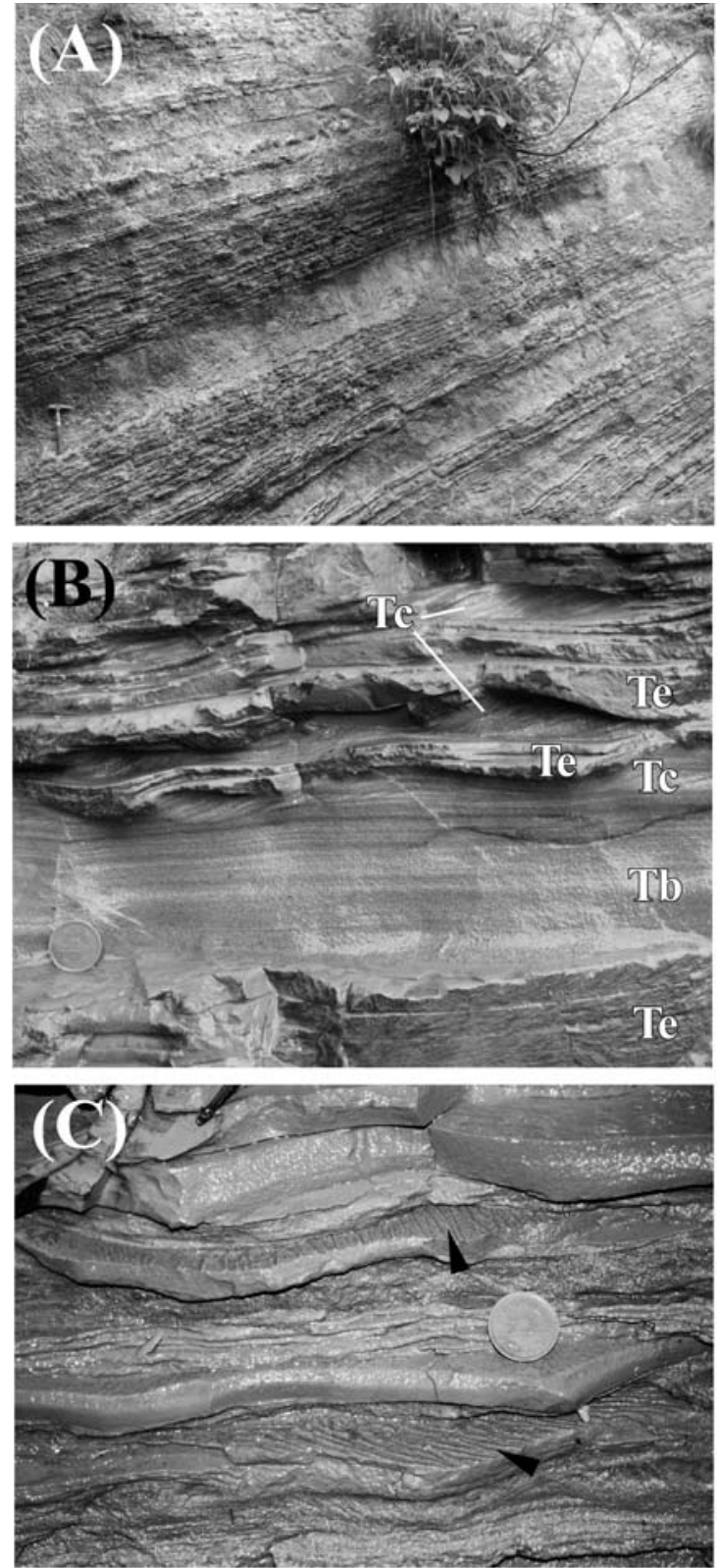

Fig. 7. Photograph of interbedded sandstone and mudstone. Locality is shown in Fig. 4. (A) Laterally continuous beds without significant erosional features. (B) Parallel-laminated sandstone, ripple cross-laminated sandstone and mudstone layers, corresponding to $\mathrm{Tb}, \mathrm{Tc}$ and Te of Bouma's turbidite division, respectively. Foresets of the ripple cross-laminated sandstone show unidirectional palaeocurrent from right of view. Coin is $23 \mathrm{~mm}$ in diameter. (C) Ridge-and-furrow molds (shown by arrows) on the upper surface of mudstone layers.

inations, whereas thinner units (less than about $2 \mathrm{~cm}$ thick) occasionally represent isolated starved ripple forms and associated unidirectional foreset laminations toe out laterally into adjacent troughs. The bases of the sandstone layers have abundant sole marks such as ridge-and-furrow molds termed by Allen (1984), which are readily recognized on somewhat weathered out upper surfaces of the 
underlying mudstone (Fig. 7.C).

Mudstone layers are apparently structureless and have a sharp boundary with the underlying and overlying sandstone layers. They consist of crystal and rock fragment, organic matter and volcanic glass. Where the mudstone layers are thinner, they conformably drape the undulating relief of ripple cross-laminated sandstone.

At two horizons throughout the middle member of the Kan-nodai Formation, dark-grey-coloured, andesite clastrich sandstone and mudstone occur (Fig. 4), which can be easily identified by its distinctive colour and are useful for stratigraphic makers owing to their widespread distribution. The andesite clasts are largely rounded to subrounded and range in size from very coarse sand to mud. Microscopic observation shows that the clasts contain phenocrysts of plagioclase, augite and hypersthene within the intersertal groundmass, whose mineral assemblages and textures are closely similar to those of the Mimizukuyama Andesite.

Interpretation: Interbedded sandstone and mudstone resembles the grain-size population and sedimentary structure of Ta, Tb, Tc and Te of Bouma's (1962) turbidite division. The imbrication of pumice fragments, asymmetrical ripple forms and unidirectional foreset laminations suggest traction sedimentation in a unidirectional current.

Analogous sole marks of ridge-and-furrow molds (Allen, 1984) have been previously described as "longitudinal current ridges" (Dzulynski, 1965) and "furrow casts" (Potter and Pettijohn, 1977). Such structures have been interpreted as erosional scour marks formed by secondary flows at the heads of turbidity currents, in which paired counter-rotating vortices occur (Dzulynski, 1965; Allen, 1984). The ridge-and-furrow molds demonstrate that turbidity currents flowed over the cohesive unconsolidated mudstone.

\section{Graded mudstone}

Description: Deposits of this facies are normally graded with basal very fine- to fine-sand and consist of crystal and rock fragments, organic matter and lesser volcanic glass. Unit thickness ranges from several centimetres to 1 $m$ thick. The upper parts appear massive but locally display crude stratification represented by colour changes and concentration of small amounts of organic matter. Bed bases are commonly flat and weakly scour the underlying beds in places.

Interpretation: The beds are interpreted to have been deposited from dilute turbidity currents, which carried fine particles (Pickering et al., 1986; Stow, 1986).

\section{Bedded mudstone}

Description: Deposits of this facies are grey to dark grey,

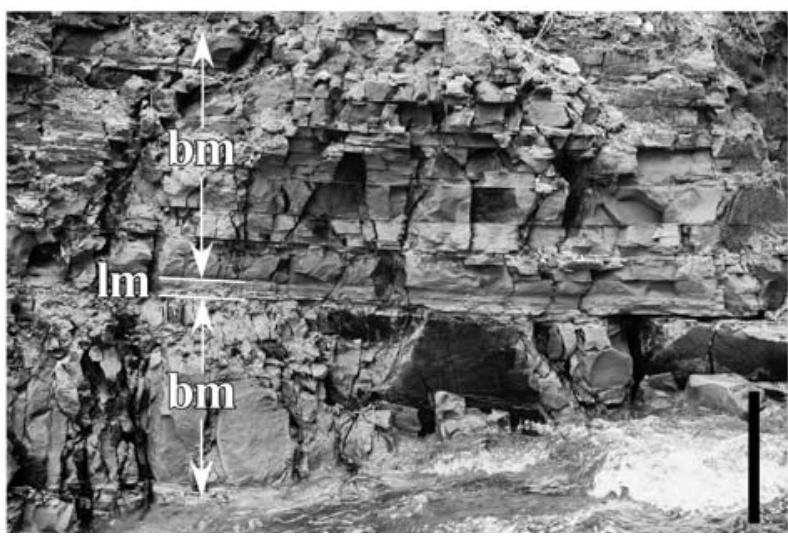

Fig. 8. Bedded mudstone (bm) intercalated with the laminated mudstone (lm). Beds are sharp, laterally continuous and show no significant erosional features. Scale bar is about $50 \mathrm{~cm}$ long. Locality is shown in Fig. 4.

massive and structureless with flat sharp bases and tops (Fig. 8). They contain abundant organic matter and crystal and rock fragment and volcanic glass. The beds range from 10 to $50 \mathrm{~cm}$ in thickness and are laterally continuous. Tiny organic fragments are scattered throughout the beds. Entirely preserved plant fossils are not present. Bioturbation is absent.

Interpretation: This facies is interpreted as cohesive debris flow deposits (Johnson, 1970). The absence of the grading and stratification suggests rapid mass deposition from debris flows.

\section{Laminated mudstone}

Description: Laminated mudstone beds are characterized by flat and laterally continuous laminae ranging from several millimetres to $10 \mathrm{~mm}$ thick (Fig. 8), which have mostly sharp contacts and variable colours of dark grey, light grey, greyish brown, or bluish grey. Individual lamina shows no internal structures, but some dark-grey and light-grey lamina forms varve-like couplets. The beds consist of crystal and rock fragments, organic matter and lesser volcanic glass. Plant fossils are preserved on bedding planes. No bioturbation is observed.

Interpretation: This facies is interpreted as the products of suspension fallout in a standing body of water. The varve-like couplets may record seasonal suspension sedimentation (Sturm and Matter, 1978).

\section{Graded pumice lapilli tuff}

Description: The deposit of this facies shows a finingupward sequence divided into five successive layers; A, B, C, D and E in ascending order (Fig. 9) and is predominantly composed of pumice lapilli and blocks and ash.

Layer A is non-stratified, poorly sorted and normally graded. The basal part is exceptionally inversely graded. Flame and ball-and-pillow structures are common. This 


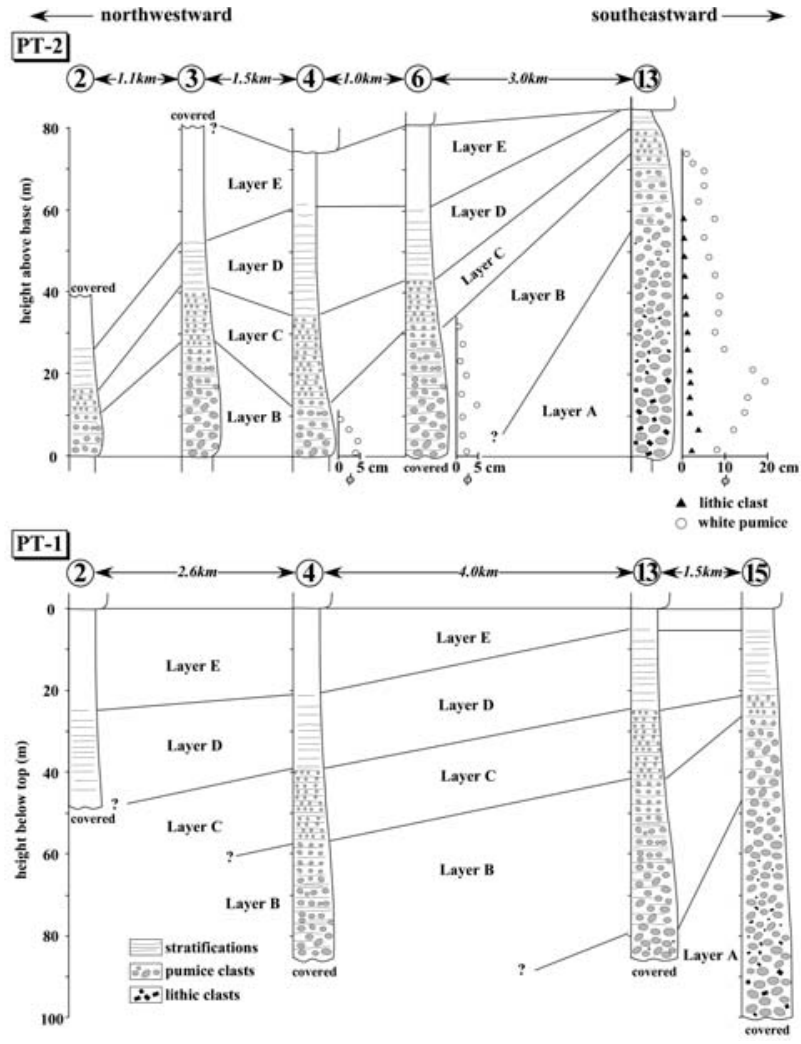

Fig. 9. Vertical and lateral facies changes of PT-1 and PT-2 with grain size distributions of pumice and lithic clasts. $\phi$ means average diameter of the ten largest clasts in the measured clasts. The localities of columns are shown in Fig. 4. Modified from Otake (2004).

layer contains pumice clasts ranging from a few centimetres to $20 \mathrm{~cm}$ in diameter and minor lithic clasts less than $5 \mathrm{~cm}$ in diameter. Layer B consists of alternations of pumice-dominated beds ( 5 to $70 \mathrm{~cm}$ thick) and lithicdominated beds ( 1 to $5 \mathrm{~cm}$ thick) showing parallel stratifications. Pumice clasts range from a few centimetres to $10 \mathrm{~cm}$ in diameter and show inverse grading and imbrication in some beds. Grain sizes of the clasts and thickness of each bed gradually decrease upward. Layer C is transitional from layer B and comprises alternations of pumicedominated beds (a few millimetres to $10 \mathrm{~cm}$ thick) and lithic-dominated beds ( 1 to $5 \mathrm{~mm}$ thick) showing parallel and cross stratifications. Outsized pumice blocks up to 30 $\mathrm{cm}$ in diameter are discernible. Layer D consists of parallel but locally cross stratified, well-sorted coarse vitric ash. Individual bed represented by colour changes are 1 $\mathrm{mm}$ to $10 \mathrm{~cm}$ thick with sharp and flat, locally deformed bases. Layer E consists of massive, well-sorted fine vitric ash and partly contains dish structures. Pumice blocks up to a few tens of centimetres occur locally. Throughout the sequence, there are no large-scale erosional discordances and no evidence for hot, gas-supported emplacement such as welding and gas segregation structures.
Entire sequences, which comprise the five layers described above, are a few tens of metres thick and extensively distributed in the middle member of the Kan-nodai Formation. Two widespread distributed sequences, PT-1 and PT-2 described by Otake (2004), are up to $100 \mathrm{~m}$ and $85 \mathrm{~m}$ thick, respectively. Incomplete sequences lacking one or more layers are also common with a thickness of a few tens of centimetres to about $50 \mathrm{~m}$, although the order in which layers occur does not change. Lateral facies change of PT-1 and PT-2 shows that coarser layers (A, B and $\mathrm{C}$ ) thin and finer layers (D and E) thicken toward the northwestern part from the southeastern part of the caldera (Fig. 9) .

Interpretation: The presence of load casts and water escape structures, and lack of evidence for hot gas-support suggest that the overall sequences were emplaced under water. The sedimentary features of the entire sequence are similar to those of high- and low-density turbidites (Lowe, 1982).

\section{Bedded fine tuff}

Description: Bedded fine tuff consists of greyish white to light grey, well-sorted vitric ash with sparse pumice fragments. Lithic clasts are absent. The beds show flat, sharp bases and tops, and are laterally continuous, ranging from 5 to about $70 \mathrm{~cm}$ in thickness. There are no internal primary structures. Unlike layer $\mathrm{E}$ of the graded pumice lapilli tuff, no water escape structures are discernible.

Interpretation: This facies is inferred to result from the fallout of glass shards through a standing body of water. Lack of water escape structures suggests a relatively low sedimentation rate.

\section{Soft-sediment deformation structures}

The middle member of the Kan-nodai Formation contains abundant soft-sediment deformation structures.

\section{Slump deposits}

Interbedded sandstone and mudstone, massive tuff breccia, and graded pumice lapilli tuff are locally deformed and disorganized within a few metres. Fig. 10.A shows that interbedded sandstone and mudstone beds and overlying massive tuff breccia are irregularly folded and partly disrupted. Associated massive tuff breccias contain several-metres-wide fragments of interbedded sandstone and mudstone beds. In some places where the contact between layer $\mathrm{C}$ and layer D of the graded pumice lapilli tuff crops out, the boundary surface is very irregular and the overlying layer D contains a large amount of disrupted rounded pieces (a few centimetres to $10 \mathrm{~cm}$ in diameter) of the underlying layer C (Fig. 10.B). Original sedimentary structures of the overlying layer D are also disorganized and partly disrupted. Lack of internal struc- 

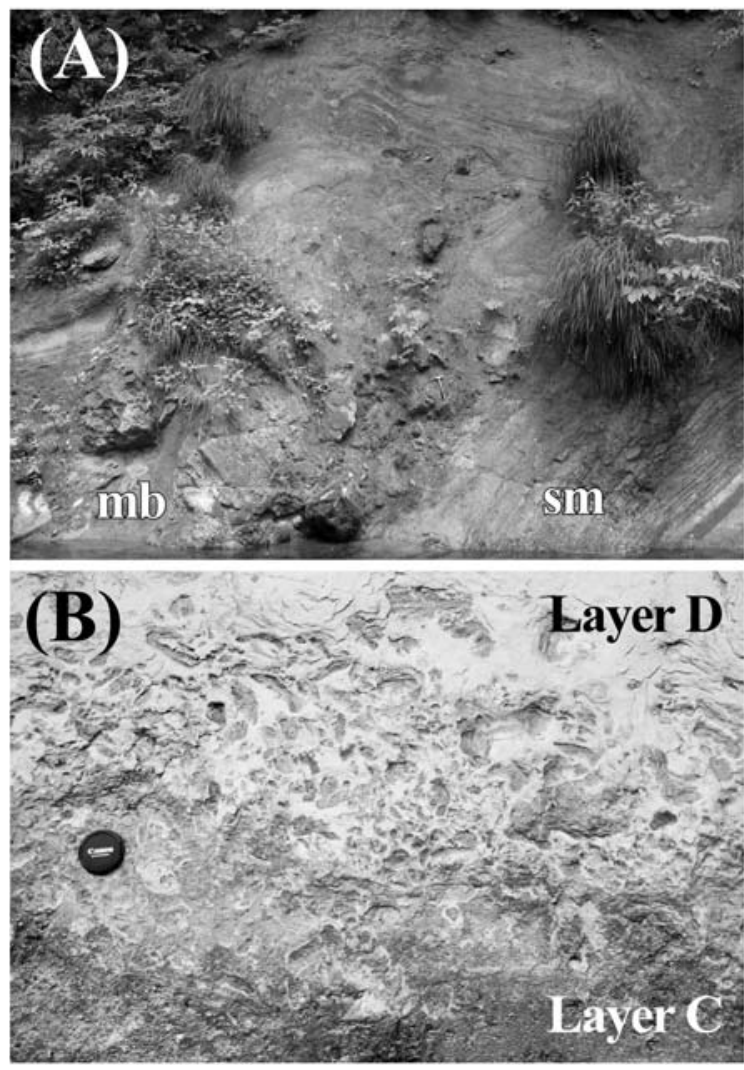

Fig. 10. Photograph of slump deposits. Locality is shown in Fig. 4. (A) Irregular boundaries between interbedded sandstone and mudstone ( $\mathrm{sm}$ ) and massive breccia (mb). Beds of sandstone and mudstone are disturbed and folded. (B) Slump structure in the graded pumice lapilli tuff. Large amounts of disrupted, rounded pieces (slump ball) of underlying layer C (interbedded pumice- and lithicdominated beds) within matrix of overlying layer D (bedded coarse tuff). Lens cap is $6 \mathrm{~cm}$ in diameter.

ture, mixed lithologies, folded beds, and rounded pieces of disrupted beds is indicative of slump deposits (Pickering et al., 1986) .

\section{Water escape structures}

Fig. 11 shows vertical and lateral injections of darkgrey-coloured fine sand and mud into the overlying bedded fine tuff. The injections, a few millimetres to $3 \mathrm{~cm}$ wide, are massive with irregular and indefinite margin, and contain small fragments of fine tuff. The bedded fine tuff also injects upward into overlying sandstone and mudstone with a flame like structure. Such injection features probably result from escape of pore water during unconsolidated state of the sediments, which is similar to Type B pillars described by Lowe (1975).

\section{Clast composition of breccias}

Clast composition of the graded breccia and the massive breccia mainly comprises fragments originated from the basement rocks (pre-Tertiary granitic rocks, Miocene

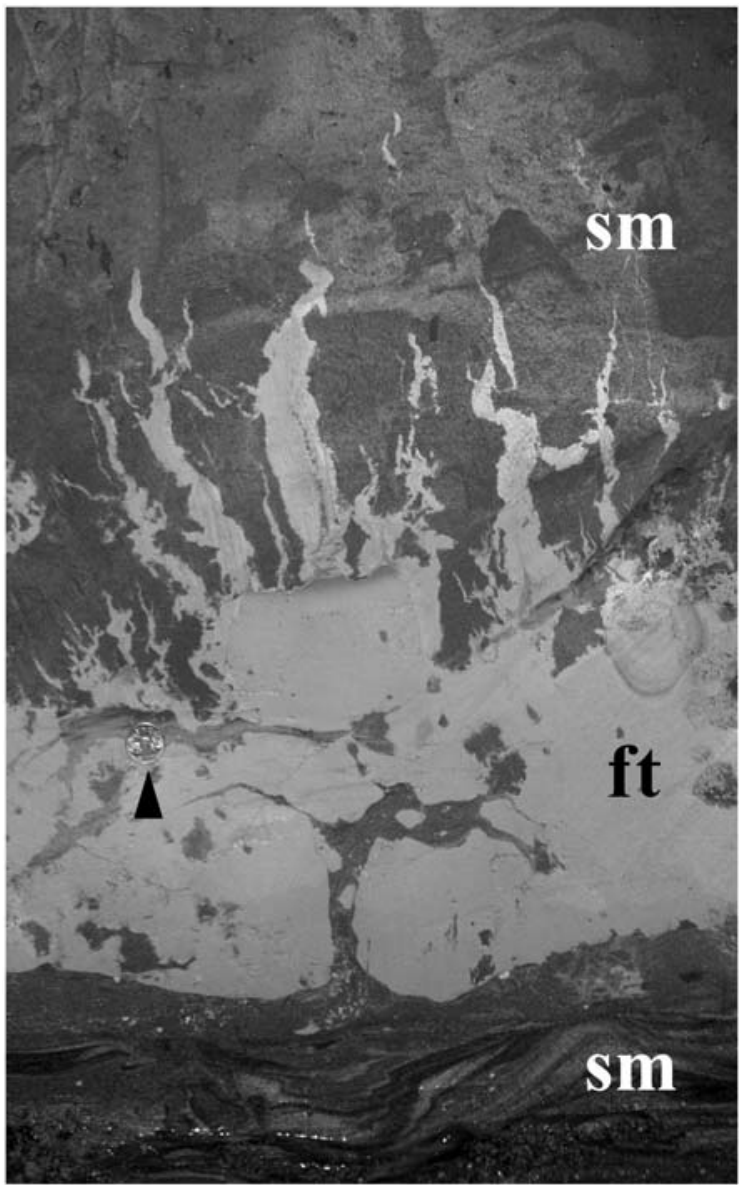

Fig. 11. Water escape structures that developed in andesite clastrich sandstone and mudstone (sm) interbedded with fine tuff (ft). Sediments inject vertically and laterally into overlying beds with irregular and indefinite margin. Coin indicated by arrow is $21 \mathrm{~mm}$ in diameter.

subaqueous volcaniclastic rocks and mudstones) and dark-grey-coloured volcanic rocks (the Mimizuku-yama Andesite), as illustrated in Fig. 12.

Clast content ratio between the basement rocks and the Mimizuku-yama Andesite shows remarkable variation with location. In the western area (localities 7, 8 and 12 in Fig. 12), most of the clasts are fragments of basement rocks. In contrast, in the eastern area (localities 13, 14 and 15 in Fig. 12), the clasts consist predominantly of the darkgrey-coloured volcanic rocks of the Mimizuku-yama Andesite, indicating that they originated from the area where the Mimizuku-yama Andesite is distributed.

\section{Palaeocurrent directions}

Palaeocurrent directions were measured using two sedimentary structures within the interbedded sandstone and mudstone: (1) dip directions of foreset laminae of the ripple cross-laminated sandstone, and (2) linear orientations of ridge-and-furrow molds on the upper surface of the 


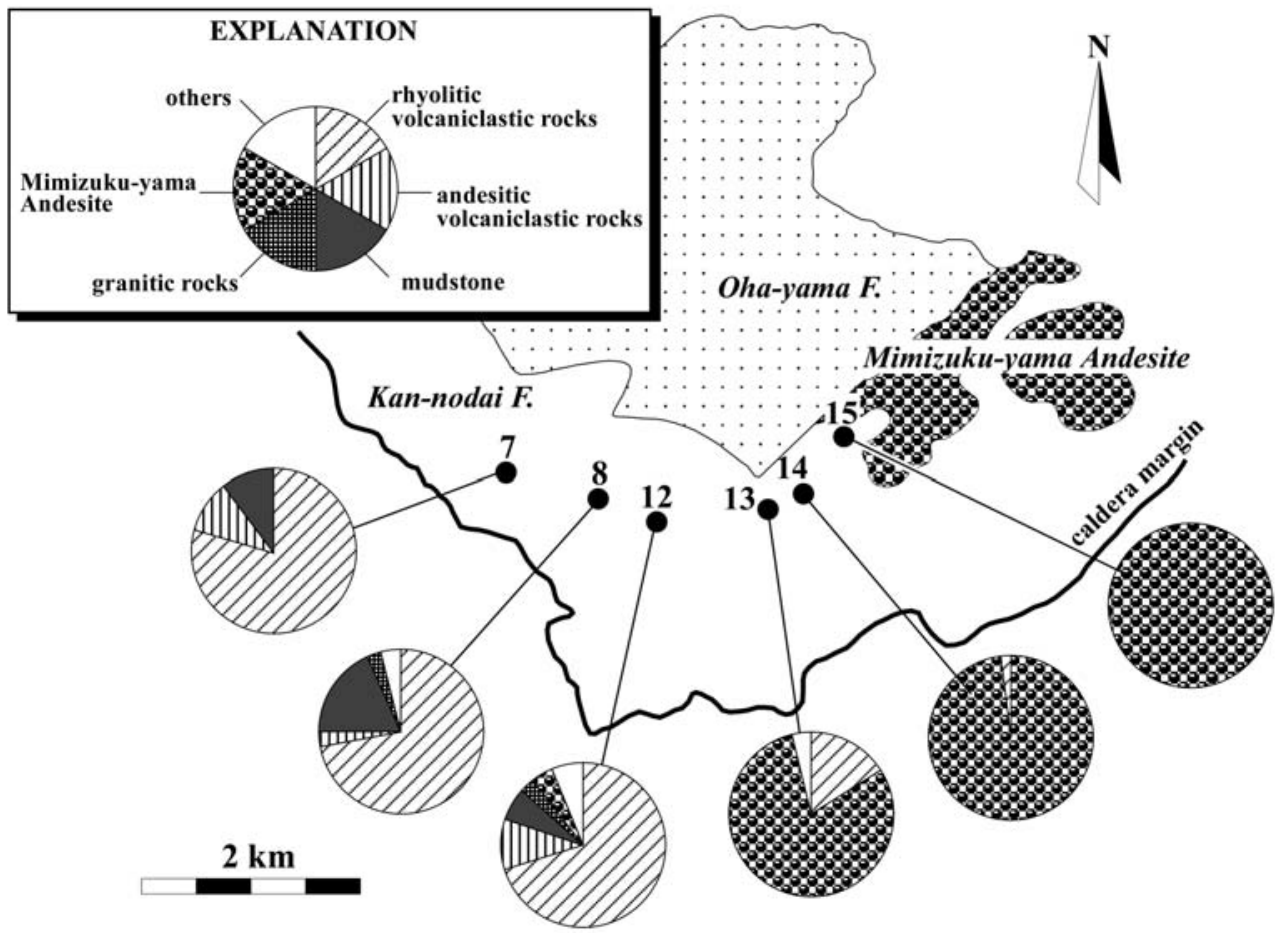

Fig. 12. Clast composition of graded breccia and massive tuff breccia, in the middle member of the Kan-nodai Formation. In each outcrop, 50 clasts were measured. Numbers with sampling localities (solid circle) denote the log numbers shown in Fig.4. Rhyolitic and andesitic volcaniclastic rocks, mudstone, granitic rocks and others belong to the basement rocks. Others are the pre-Tertiary metamorphic rocks and chert.

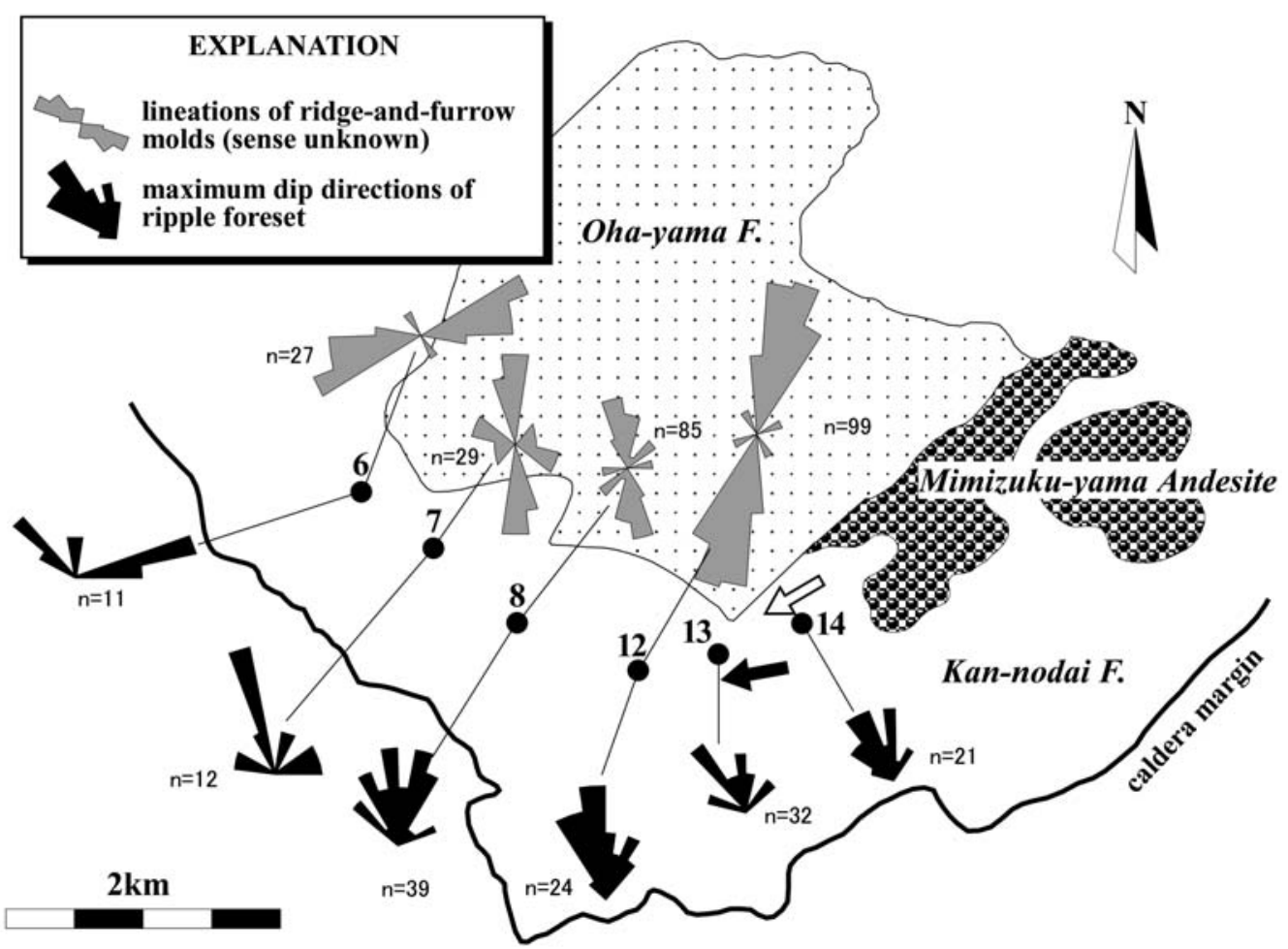

Fig. 13. Orientations of the foresets of the ripple cross-laminated sandstone and the ridge-and-furrow molds on the upper surface of the mudstone. Numbers with sampling localities (solid circle) denote the log numbers as shown in Fig. 4. Open and solid arrows indicate palaeocurrent directions which were determined from the pumice imbrications and the ripple cross-laminations in the graded pumice lapilli tuff (Otake, 2004). 
Table 2. Summary of the facies associations in the middle and upper members of the Kan-nodai Formation.

\begin{tabular}{llll}
\hline Facies association & Major facies & Minor facies & Remarks \\
\hline Slope apron & $\begin{array}{l}\text { Mssive tuff breccia } \\
\text { Interbedded sandstone and mudstone } \\
\text { Graded pumice lapilli tuff }\end{array}$ & $\begin{array}{l}\text { Graded breccia } \\
\text { Bedded fine tuff }\end{array}$ & $\begin{array}{l}\text { Slump beds } \\
\text { Water escape structures }\end{array}$ \\
& $\begin{array}{l}\text { Graded mudstone } \\
\text { Bedded mudstone } \\
\text { Graded pumice lapilli tuff }\end{array}$ & $\begin{array}{l}\text { Laminated mudstone } \\
\text { Bedded fine tuff }\end{array}$ & Plant fossils \\
& Glain & & \\
\hline
\end{tabular}

mudstone. The measured data were corrected for local structural dip. The result is summarized in Fig. 13.

Foreset laminae of the ripple cross-laminated sandstone show NNE- to NNW-palaeocurrents directions at localities 7, 8, 12, 13 and 14 in Fig. 13, and ENE-palaeocurrents directions at locality 6 . It seems that overall the palaeocurrent directions are roughly normal to the strike of the adjacent caldera margin, though some are parallel. Namely, interbedded sandstone and mudstone were dominantly transported toward the caldera basin. The dominant foreset direction of locality 12 is consistent with the palaeocurrent direction inferred from the imbrication of pumice clasts in the parallel laminated sandstone. Dominant orientations of ridge-and-furrow molds are aligned N-S to NNE-SSW at localities 7, 8, 12, 13 and 14, and ENE-WSW at locality 6 . Most of the orientations are roughly parallel or somewhat perpendicular to the dominant foreset direction of ripple cross-laminae at each locality.

Otake (2004) reported that the palaeocurrents of the graded pumice lapilli tuff show a SW- to WSW- trend near locality 14 (Fig. 13). These directions are different from those of the interbedded sandstone and mudstone, suggesting different sediment sources.

\section{Facies associations}

Eight facies in the middle and upper members of the Kan-nodai Formation constitute two facies associations, A and B (Table 2).

Facies association A is composed predominantly of massive tuff breccia, interbedded sandstone and mudstone, and graded pumice lapilli tuff together with graded breccia and bedded fine tuff (Figs. 3, 4 and 14). It spreads widely in the caldera basin around the Mt. Oha-yama resurgent dome and corresponds to the distribution of the middle member of the Kan-nodai Formation (Figs. 3 and 4). Graded pumice lapilli tuff is especially predominant and two thick upward-fining sequences, PT-1 and PT-2 described by Otake (2004), can be traced laterally throughout the middle member of the formation (Fig. 4).

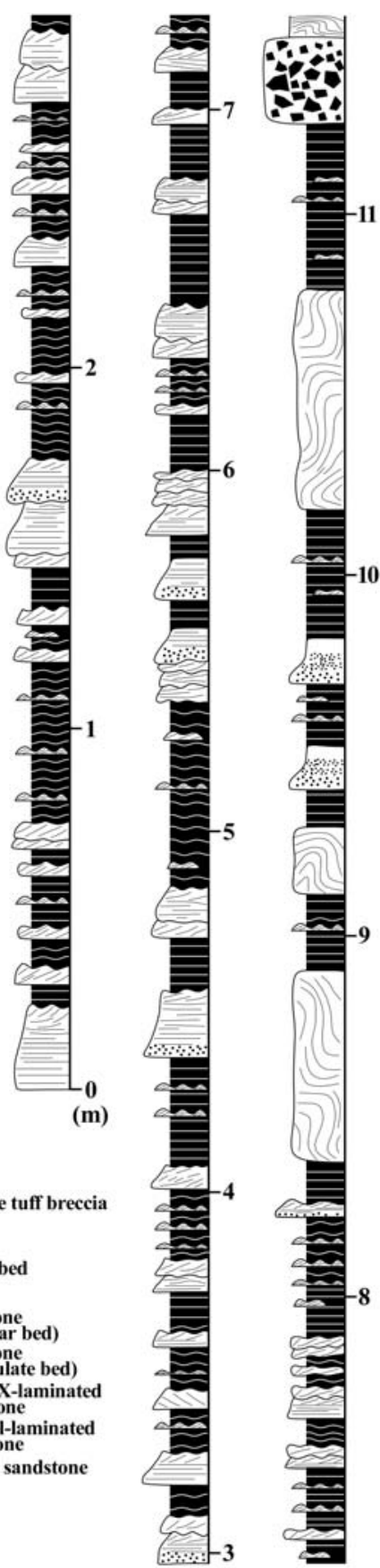

Fig. 14. Detailed logs of the slope apron facies association. Locality of logs is shown in Fig. 4. 


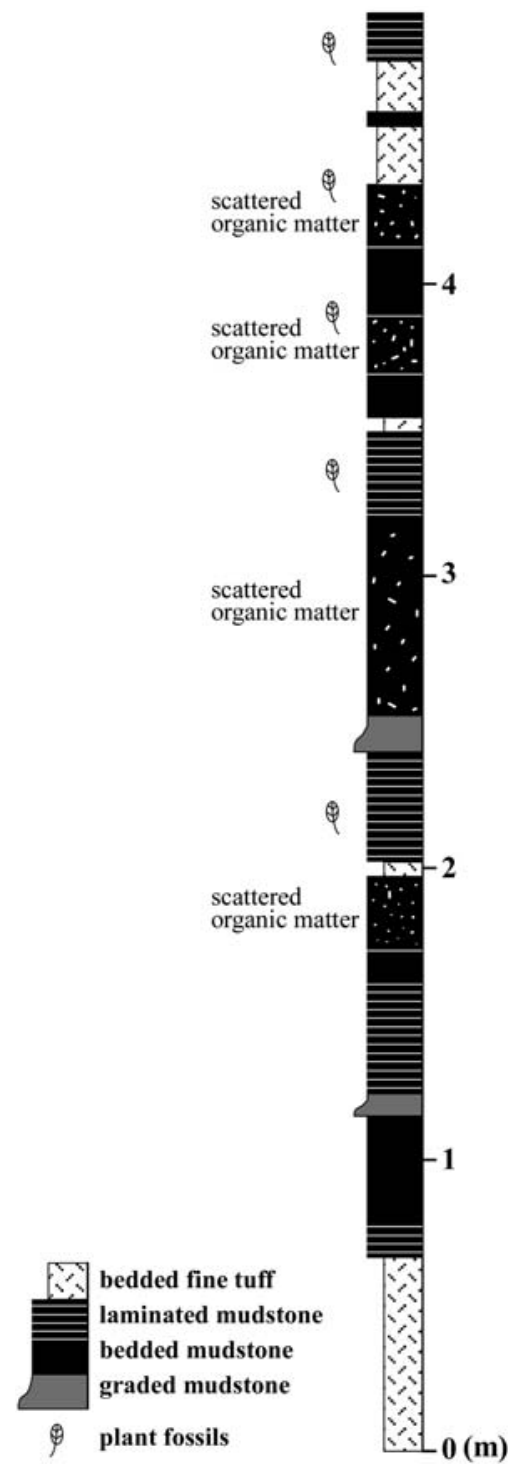

Fig. 15. Detailed log of the basin plain facies association. Locality of log is shown in Fig. 4.

Slump deposits evidenced by soft-sediment deformation structures are also common. In the geologic columns (Fig. 4 ), there seems to be no significant vertical and lateral relationship of these facies. As illustrated in the detailed log in Fig. 14, there is a lack of systematic vertical trends such as fining/thinning-upward or coarsening/thickeningupward cycles. Additionally, the slump deposits appear to occur randomly.

Facies association B consists predominantly of graded mudstone, bedded mudstone and graded pumice lapilli tuff together with laminated mudstone and bedded fine tuff (Figs. 3, 4 and 15). This facies contains no slump deposits and few traction structures but many plant fossils. No vertical systematic facies change is discernible in any outcrops. This facies association, which overlies facies association A, is restricted only in two narrow areas; the southern and western parts of the caldera, and corresponds to the distribution of the upper member of the Kan-nodai Formation.

\section{Discussion}

\section{Sedimentary environments}

Sedimentary processes of facies association A were dominated by sediment gravity flows such as turbidity currents and debris flows. Close spatial association of turbidites, debris flow deposits, and slump deposits (Figs. 4, 14) indicates recurrence of downslope redeposition of sediment by slump on an unstable slope. Local variation of clast composition of breccias (Fig. 12) and basinward palaeocurrents (Fig. 13) indicate transport of sediments from the caldera rim. There is no evidence for a substantial fluvial input to the caldera lake. Lateral continuous thin beds favour deposition from unconfined sheet flows rather than flows in confined narrow valleys (e.g. Nelson and Maldonado, 1988). Facies association A is interpreted to represent a slope apron depositional system of the caldera lake. A few systematic depositional patterns and multiple sediment sources inferred from this study are also distinctive features at marine slope apron systems documented by Ineson (1989) and Lomas (1999).

Sedimentary processes of facies association B are dominated by fine-grained sediment gravity flows and suspension fallout. Laterally continuous sharp beds and laminae without large-scale erosional bases and bioturbation indicate deposition in a flat, low-energy basin plain of the caldera lake, in which coarse-sediment supply is not affected.

Throughout facies associations A and B, the absence of wave-induced sedimentary structures implies deposition below the wave base. Considering the total thickness of the two thick graded pumice lapilli tuff sequences (PT-1 and PT-2 in Fig. 4), which were emplaced wholly subaqueously, the water depth prior to their depositions was at least $200 \mathrm{~m}$.

Well-documented examples of sedimentary environments in caldera lakes include the modern Crater Lake caldera (Nelson et al., 1986, 1994; Bacon et al., 2002) and the Oligocene Creede caldera (Larsen and Crossey, 1996; Heiken et al., 2000). The present-day Crater Lake, which is $10 \mathrm{~km}$ in diameter and $600 \mathrm{~m}$ deep, is topographically closed without any major inlet and outlet and caldera walls slope about 30 to $45^{\circ}$ (Nelson et al., 1986; Bacon et al., 2002). Sedimentary processes are dominated by sediment gravity flows which transport debris from the caldera walls into the lake, and their deposits show nonchannelized thick, coarse-grained beds on the slope apron 
and thin, finer-grained beds on the basin plain (Nelson et al., 1986, 1994), similar to the Akakura caldera. The ancient lake of the Creede caldera has been also filled by a slope apron system, which is characterized by the lack of well organized turbidites, debris flow deposits and laminated siltstone (Larsen and Crossey, 1996).

\section{Evolution of the ancient lake of the Akakura caldera}

The Akakura caldera was formed due to the eruption of voluminous ash-flow and concurrent subsidence of the central basement rock along ring faults (Otake, 2000). The primary collapse structure possibly bounded by a structural caldera wall (ring fault) was inferred to be about $5 \mathrm{~km}$ in diameter (Otake, 2000). Considering the regional tumescence prior to the climactic eruption (Otake, 2000), the caldera collapse probably occurred at the center of a topographic high rather than a broad lowland. It is thus likely that the resulting caldera basin has been confined by steeply dipping walls and the surrounding topographic surface dipped outward from the caldera. Initial postcaldera sedimentation occurred just after caldera collapse, corresponding to the deposition of the lower member of the Kan-nodai Formation. According to the author's preliminary study, the lower member of the formation was possibly deposited in an alluvial environment, because of the facies association of the breccia and sandstone interpreted as debris flow and hyperconcen- trated flow deposits.

Following the alluvial sedimentation, lacustrine sedimentation occurred in the caldera basin, indicated by the slope apron and basin plain deposits (Fig. 16). The appearance of the middle member of the Kan-nodai Formation clearly shows periods when water began to accumulate within the caldera basin and a lake was formed. The sedimentation on the slope apron at the basin margin was dominated by sediment gravity flows that must have resulted from slope failures of the unstable caldera wall. Such slope failures led to a retreat of the wall and enlargement of the topographic caldera margin, as opposed to the structural caldera margin that bounds the original collapse basin. This is supported by a significant gap in distance between the original structural wall (about $5 \mathrm{~km}$ in diameter) and the present-day topographic wall (about 10 $\mathrm{km}$ in diameter), indicating that the lacustrine sedimentation was largely governed by the episodic and random slope failures on the unstable caldera wall.

Deposition of the basin plain deposits indicates that the sedimentary environment changed from the slope apron to the basin plain. Dominant mudstone facies clearly implies that coarse sediment supply from the caldera wall decreased. This fining-upward succession from the slope apron to basin plain deposits is likely to reflect the retrogradational fill which results from (1) the retreat of the caldera wall due to slope failures, and (2) the rise of the

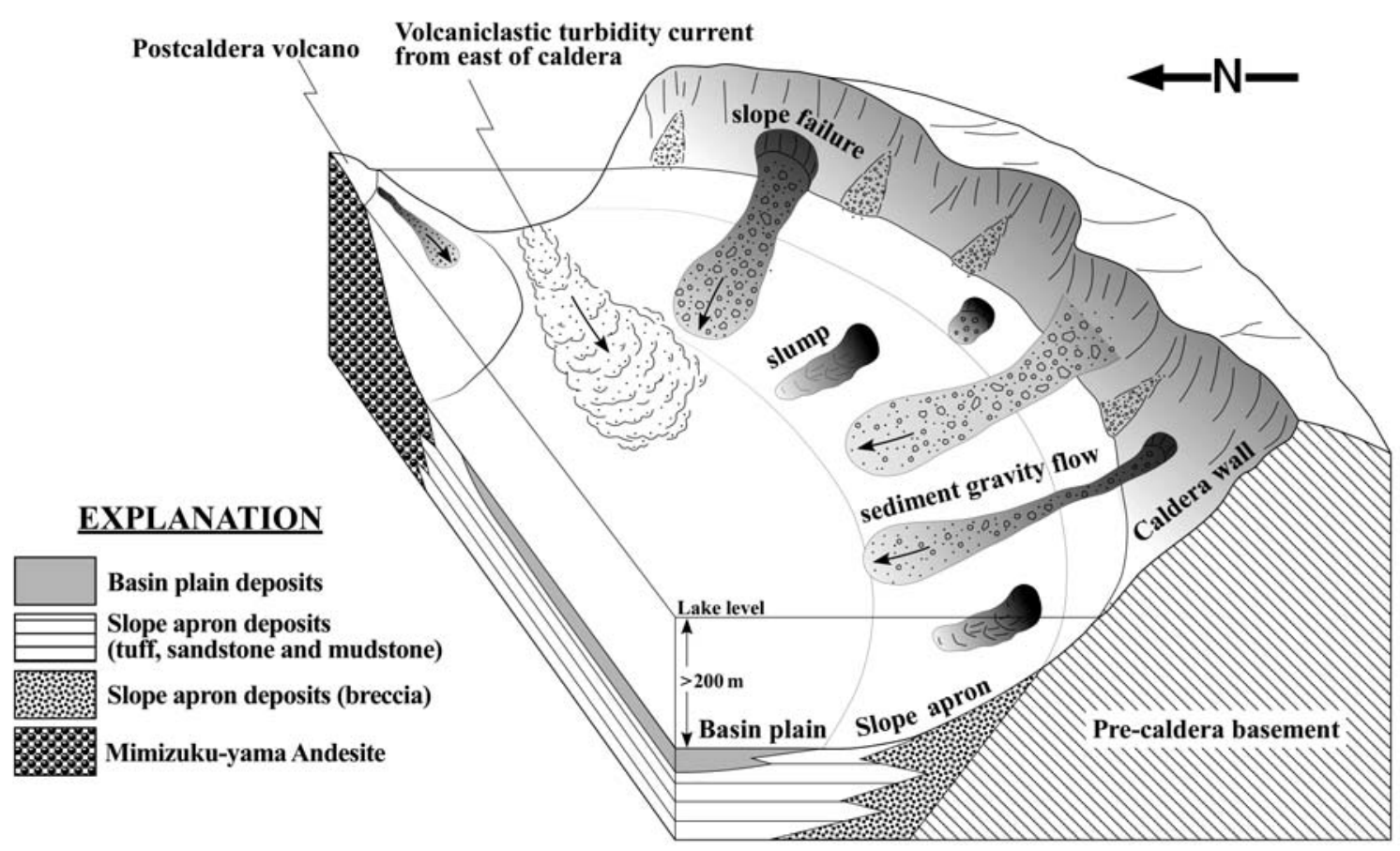

Fig. 16. Schematic diagram of the palaeogeography and the sedimentary environments during the sedimentation of the middle and upper members of the Kan-nodai Formation in the ancient lake of the Akakura caldera. Arrows show the directions of sediment supply. 
lake level with increasing water volume within the caldera. Indeed, there is no evidence such as large-scale erosional features for a significant fall in water level in the preserved lacustrine deposits.

\section{Influence of volcanism on lacustrine sedimenta- tion}

The graded pumice lapilli tuff, the bedded fine tuff and the andesite clast-rich sandstone and mudstone provide information on postcaldera volcanism and associated volcaniclastic sedimentation in the lake.

Voluminous accumulations of the pyroclastic materials of graded pumice lapilli tuff and bedded fine tuff are indicative of the influence of felsic explosive eruptions during lacustrine sedimentation, irrespective of whether they primarily originated from the volcanism or resedimented. Fission track age of the pumice within the graded pumice lapilli tuff is inferred to be $0.8 \pm 0.2$ and $1.1 \pm$ $0.2 \mathrm{Ma}$ (NEDO, 1990). Assuming that thick graded pumice lapilli tuffs (PT-1 and PT-2) cover the caldera lake, the volume is calculated to be about $14 \mathrm{~km}^{3}$. Taking account of other minor graded pumice lapilli tuff and bedded fine tuff, the total volume of the pyroclastic materials in the lake is inferred to be more than $20 \mathrm{~km}^{3}$. In general, eruption of such voluminous pyroclastic materials could result in caldera collapse (Smith, 1979; Cas and Wright, 1987). There is no field evidence for vents of pyroclastic eruptions within the Akakura caldera. The caldera structure close to the Akakura caldera includes the Onikobe, the Mukaimachi, and the Nakayamadaira calderas (Fig. 1). The Onikobe caldera is not likely to be source area of the graded pumice tuff, because caldera-forming pyroclastic flow deposits of the Onikobe caldera have fission track ages of $0.21 \pm 0.09$ and $0.25 \pm 0.07 \mathrm{Ma}$ (Tsuchiya et al., 1997). The radiometric age of the Mukaimachi and Nakayamadaira calderas has not been obtained, but continuity, preservation and contact relationship of topographic caldera margins may suggest that the Mukaimachi and Nakayamadaira calderas are younger than the Akakura caldera. A lateral facies change of the graded pumice lapilli tuffs (PT-1 and PT-2) represents flow from the southeastern part of the Akakura caldera (Fig. 9). In addition, the palaeocurrent data as shown in Fig. 13 demonstrate that PT-1 and PT-2 were sourced from the eastern part of the caldera. Therefore, the voluminous pyroclastic materials of the Akakura cakdera are likely to have been derived from an area east of the lake (Fig. 16), possibly the Nakayamadaira caldera.

Otake (2004) considered that PT-1 and PT-2 were originated from sediment gravity flows generated directly by progressive sorting of a subaqueous eruption column from the vent of a postcaldera andesite volcano. According to previous experiments (Whitham and Sparks, 1986; White et al., 2001), hot pumice ejected into water can be initially buoyant due to steam generation within the pumice fragments before cooling and sinking. This forms inversely graded deposits due to larger pumice fragments taking longer to cool and sink. On the other hand, fully water saturated, cold pumice sinks at rates proportional to grain size to form normally graded pumice deposit. Therefore, the normally graded pumice of PT- 1 and PT- 2 may be attributed to a redeposition of water-saturated pumice from sediment gravity flows rather than primary deposition. Rounded to sub-rounded pumice clasts within interbedded sandstone and mudstone beds suggest that the pumice was also reworked and mixed into basement detritus produced by slope failures on the unstable caldera wall.

The andesite clast-rich sandstone and mudstone indicate that andesitic volcanism concurrently occurred during the lacustrine sedimentation of the middle member of the Kan-nodai Formation. The andesite fragments resembling the Mimizuku-yama Andesite represent the sources from the area around Mts. Mimizuku-yama and Futatsumori-yama. Because the Mimizuku-yama Andesite consists of coherent lava and hyaloclastite, the volcanism can be regarded as effusive eruption in a subaqueous environment. However, abundance of rounded to sub-rounded sand-sized andesite fragments implies that the sediments were not directly derived from the subaqueous volcanic vents but were transported from subaerial to shallow subaqueous areas of the andesite volcano, probably in beach or shoreface environments, as sediment gravity flows (Fig. 16). Thus, it is likely that the andesite volcano partly emerged above the water surface or wave base and partly eroded. Seismic shocks caused by such eruptions are likely to have triggered the slope failures of the caldera wall, and the slump and water escape to form extensive soft-sediment deformation structures.

\section{Conclusions}

Lake deposits of the Akakura caldera comprise slope apron and basin plain deposits. Slope apron deposits of the Akakura caldera are dominated by turbidites and debris flow deposits produced by slope failures on the unstable caldera wall. The basin plain deposits are dominated by fine-grained turbidites and debris flow deposits, and suspension fallout deposits. Fining-upward succession from the slope apron to basin plain deposits of the Akakura caldera reflects retreat of the caldera wall due to slope failures, and rise of lake level with increasing water volume within the caldera. Lake deposits in the Akakura caldera record volcanic activities of felsic pyroclastic 
eruptions in the area east of the lake and postcaldera andesitic effusive eruptions.

\section{Acknowledgments}

I am very grateful to Prof. K. Amano of Ibaraki University for his important advice and for critical review of the manuscript. I also thank Prof. K. Yagishita of Iwate University for his helpful advice in the field, Prof. H. Sato of the Earthquake Research Institute, University of Tokyo for his valuable suggestions in the early stage of the work, and Dr. A. J. Martin of NAGRA for language revision. The manuscript was significantly improved after critical comments from Dr. K. Kano of the Geological Survey of Japan and an anonymous reviewer. Thanks are also due to the editor, Dr. M. Ban of Yamagata University for his helpful comments.

\section{References}

Allen, J.R.L., 1984, Sedimentary structures, their character and physical basis, Vol. II. Developments in Sedimentology 30, Elsevier, Amsterdam, 663p.

Amano, K. and Sato, H., 1989, Neogene tectonics of the central part of Northeast Honshu Arc. Mem. Geol. Soc. Japan, no.32, 81-96.**

Awata, Y., 1984, Late Miocene to Pliocene calderas in the Northeast Japan. Bull. Geol. Surv. Japan, 35, 439-440.*

Bacon, C.R., Gardner, J.V., Mayer, L.A., Buktenica, M.W., Dartnell, P., Ramsey, D.W. and Robinson, J.E., 2002, Morphology, volcanism, and mass wasting in Crater Lake, Oregon. Geol. Soc. Amer. Bull., 114, 675-692.

Bouma, A.H., 1962, Sedimentology of some flysh deposits; A graphic approach to facies interpretation. Elsevier, Amsterdam, 168p.

Cas,R.A.F. and Wright,J.V., 1987, Volcanic successions, moderm and ancient. Allen \& Unwin, 528p.

Dzulynski, S., 1965, New data on experimental production of sedimentary structures. Jour. Sediment. Petrol., 35, 196-212.

Heiken, G., Krier, D., McCormick, T. and Snow, M.G., 2000, Intracaldera volcanism and sedimentation- Creede caldera, Colorado. In Bethke, P.M. and Hay, R.L. eds., Ancient Lake Creede: Its volcano-tectonic setting, history of sedimentation, and relation to mineralization in the Creede Mining District. Geol. Soc. Amer. Spec. Pap., no. 346, 127-157.

Ineson, J,R., 1989, Coarse-grained submarine fan and slope apron deposits in a Cretaceous back-arc basin, Antarctica. Sedimentology, 36, 793819.

Ito, T., Utada, M.. and Okuyama, T., 1989, Mio-Pliocene calderas in the Backbone Region in northeast Japan. Mem. Geol. Soc. Japan, no.32, 409-429. **

Johnson, A.M., 1970, Physical processes in Geology. Freeman, Cooper and Company. San Francisco, 577p

Kondo, H., Tanaka, K., Mizuochi, Y. and Ninomiya, A., 2004, Long-term changes in distribution and chemistry of middle Miocene to Quaternary volcanism in the Chokai-Kurikoma area across the Northeast Japan Arc. Island Arc, 13, 18-46.

Larsen, D. and Crossey, L.J., 1996, Depositional environments and paleolimnology of an ancient caldera lake: Oligocene Creede Formation, Colorado. Geol. Soc. Amer. Bull., 108, 526-544.

Lipman, P.W., 1997, Subsidence of ash-flow calderas: relation to caldera size and magma-chamber geometry. Bull. Volcanol., 59, 198-218.

Lomas, S.A., 1999, A Lower Cretaceous clastic slope succession, Livingston Island, Antarctica: sand-body characteristics, depositional processes and implications for slope apron depositional models. Sedimentology, 46, 477-504.

Lowe, D.R., 1975, Water escape structures in coarse-grained sediments.
Sedimentology, 22, 157-204.

Lowe, D.R., 1982, Sediment gravity flows: II. Depositional models with special reference to the deposits of high-density turbidity currents. Jour. Sediment. Petrol., 52, 279-297.

Middleton, G.V. and Hampton, M.A., 1976, Subaqueous sediment transport and deposition by sediment gravity flows. In Stanley, D.J. and Swift, D.J.P. eds., Marine sediment transport and environmental management. John Wiley, New York, 197-218.

Morimoto, R., 1942, On the Tertiary formation between Nakayamadaira and Mukaimati. Japan Ass. Petrol. Technologists, Jour., 10, 260271.*

NEDO (New Energy and Industrial Technology Development Organization), 1990, Report on the Geothermal Development Promotion Survey in the Mogami Akakura area. 808p.*

Nelson, C.H. and Maldonado, A., 1988, Factors controlling depositional patterns of Ebro turbidite systems, Mediterranean sea. Bull. Amer. Ass. Petrol. Geol., 72, 698-716.

Nelson, C.H., Meyer, A.W., Thor, D. and Larsen, M., 1986, Crater Lake, Oregon: A restricted basin with base-of-slope aprons of nonchannelized turbidites. Geology, 14, 238-241.

Nelson, C.H., Bacon, C.R., Robinson, S.W., Adam, D.P., Bradbury, J.P., Barber, J.H..Jr., Schwartz, D. and Vagenas, G., 1994, The volcanic, sedimentologic, and paleolimnologic history of the Crater Lake caldera floor, Oregon: Evidence for small caldera evolution. Geol. Soc. Amer. Bull., 106, 684-704.

Otake, M., 2000, Stratigraphy and styles of caldera-forming eruption and subsidence of the Akakura caldera in the South Kurikoma geothermal area, Northeast Japan. Jour. Geol. Soc. Japan, 106, 205-222.**

Otake, M., 2004, Lithofacies and sedimentary processes of volcaniclastic sediment gravity flow deposits emplaced in a caldera lake, the Pleistocene Kan-nodai Formation in the South Kurikoma geothermal area, Northeast Japan. Jour. Geol. Soc. Japan, 110, 331-347.**

Pickering, K.T., Stow, D.A.V., Watson, M.P. and Hiscott, R.N., 1986, Deepwater facies, processes and models: a review and classification scheme for modern and ancient sediments. Earth-Sci. Rev., 23, 75174.

Potter, P.E. and Pettijohn, F.J., 1977, Paleocurrents and basin analysis, Second, corrected and updated edition. Springer-Verlag, Berlin Heidelberg, 425p

Smith, R.L., 1979, Ash-flow magmatism. Geol. Soc. Amer. Spec. Pap., no. $180,5-27$

Smith, R.L. and Bailey, R.A., 1968, Resurgent cauldrons. Geol. Soc. Amer. Mem., 116, 613-662.

Stow, D.A.V., 1986, Deep clastic seas. In Reading, H.G. ed., Sedimentary environment and facies. Second edition. Blackwell Scientific Publ. $399-444$.

Sturm, M. and Matter, A., 1978, Turbidites and varves in Lake Brienz (Switzerland): deposition of clastic detritus by density currents. In Matter, A. and Tucker, M.E. eds., Modern and ancient lake sediments. Spec. Publs. int. Ass. Sediment., no.2, 147-168.

Taguchi, K., 1961, Stratigraphical studies of the Neogene Tertiary in the southern part of the Oguni river, Mogami-gun, Yamagata Prefecture. Geological studies of the "Dewa geosyncline", northern Honshu IV. Jour. Geol. Soc. Japan, 67, 157-170.**

Taguchi, K., 1975, Geological map of Narugo at 1: 50,000 and explanatory text. Yamagata Prefectural Government, 14p.*

Tsuchiya, N., Itoh, J., Seki, Y. and Iwaya, T., 1997, Geology of the Iwagasaki district, with Geological Sheet Map at 1: 50,000. Geol. Surv. Japan, 96p.**

Uemura, K., 1977, Late Miocene floras in the Japan Sea side district of Northeast Honshu, Japan. Professor Kazuo Huzioka Memorial Volume, 333-343.**

Utada, M. and Ito, T., 1989, Sedimentary facies of the Mio-Pliocene volcanotectonic depressions along the volcanic front in northeast Honshu, Japan. In Taira, A. and Masuda, F., eds., Sedimentary facies in the active plate margin, Terra Scientific Publishing Company, Tokyo, 605-618.

White,J.D.L., Manville,V., Wilson,C.J.N., Houghton,B.F., Riggs,N.R. and Ort,M., 2001, Setting and depositional of AD 181 Taupo pumice in 
lacustrine and associated environments. In White,J.D.L. and Riggs,N.R. eds., Volcaniclastic Sedimetation in Lacustrine Settings. Spec.Publs.int.Ass.Sediment., no.30, 141-150.

Whitham,A.G. and Sparks,R.S.J., 1986, Pumice. Bull.Volcanol, 48, 209223.

地名・地層名

Akakura 赤倉

Asahi-zawa R. 朝日沢

Eai-gawa R. 江合川

Gando-sawa R. 岩堂沢

Hitohane Formation 一訽層

Jingamori 陣ヶ森

Kan-nodai Formation 管ノ平層

Kurikoma

Mt. Daimyojin-yama

Mt. Mimizuku-yama

Mt. Oha-yama
栗駒

大明神山

みみずく山

奥羽山

Yamada, E., 1972, Study on the stratigraphy of Onikobe area, Miyagi prefecture, Japan -with special reference to the development of the Onikobe Basin-. Geol. Surv. Japan. Bull., 23, 217-231.

* : in Japanese

** : in Japanese with English abstract

Mt. Futatsumori-yama

Mimizuku-yama Andesite

Mukaimachi

Myojin-gawa R.

Narugo

Nakayamadaira

Oguni-gawa R.

Oana-sawa R.

Oha-yama Formation

Onikobe

Sakaida

Sue-sawa R.

Yakashiwa-sawa R.
二ツ森山

みみずく山安山岩

向町

明神川

鳴子

中山平

小国川

大穴沢

奥羽山層

鬼首

堺田

末沢

矢柏沢

（要 旨）

Otake. M., 2007, Sedimentary facies, processes and environments of the Akakura caldera lake, the South Kurikoma geothermal area, northeast Japan. Jour. Geol. Soc. Japan, 113, 549-564. (大竹正巳, 2007, 栗駒南部地熱地域, 赤倉カルデラ湖の堆積相, 堆積作用およ び堆積環境. 地質雑, 113, 549-564.)

栗駒南部地熱地域に分布する更新統管ノ平層中〜上部は，赤倉カルデラ湖のスロープエ プロンと堆積盆底の堆積物から構成される。管ノ平層中部に相当するスロープエプロン堆 積物は，カルデラ壁崩壊に由来する土石流や混濁流によってもたらされた砶岩や砂岩泥岩 互層を主体とし，スランプ構造が発達する。管ノ平層上部に相当する堆積盆底堆積物は, 低密度の堆積物重力流や懸濁物質の降下堆積による泥岩が卓越し，植物化石を産する。 ス ロープエプロンと堆積盆底の堆積物には，軽石に富む火山砕屑物が多量に挟在する，スロ ープエプロン堆積物から堆積盆底堆積物への上方細粒化は，重力的に不安定なカルデラ壁 の斜面崩壊や湖水面上昇によって砕屑物の供給域が後退したことに起因する。 カルデラ湖 の埋積作用には，カルデラ壁の斜面崩壊に由来する基盤岩の砕屑物に加え，カルデラ南東 部の後カルデラ期火山活動で生成された安山岩質火砕岩と，カルデラ東方を給源とする珪 長質火山砕屑物の供給が関与していた。 